\title{
„MADÁRKA A KALITKÁBAN"? \\ TUDOMÁNYKÖZISÉG AZ IRODALOM KUTATÁSÁBAN ÉS OKTATÁSÁBAN
}

\author{
'BIRDY IN THE CAGE'? \\ TRANSDISCIPLINARITY IN LITERARY STUDIES AND LITERARY EDUCATION
}

\author{
Hetényi Zsuzsa \\ egyetemi tanár, az MTA doktora \\ Eötvös Loránd Tudományegyetem Bölcsészettudományi Kar \\ hetenyi@elte.hu
}

\begin{abstract}
ÖSSZEFOGLALÁS
Mire "jók" a humán vagy bölcsészeti tudományok, és mennyire tudományok - ez a közkeletű és régi kérdés egyre élesebb hangnemben vetődik fel állami döntéshozók kontextusaiban. A nem csak szakembereknek szánt cikk rákérdez, mi is tekinthető ma a tudományosság kritériumának, és a hasznosságról gondolkodik egy szűkebb terület, a szépirodalom mintáján. Felveti a kérdést, mi az irodalom olvasása, elemzése és kutatása közötti különbség, és mi az utóbbiak haszna? Érvelésének célja, hogy a bölcsészettudomány és a "kemény" tudományok közötti hagyományosan elképzelt választóvonalakat megkérdőjelezve a tudományterületek egymás felé tartását, hasonlóságát és összefüggését helyezze előtérbe, a humán tudományok primer nélkülözhetetlenségét hangsúlyozva minden egyes ember számára.
\end{abstract}

\section{ABSTRACT}

The common question about the usefulness of human studies is an old one but recently it has been raised by decision-makers in more and more acute contexts. The comprehensive essay below dwells on some definitions around the criteria of 'sciences' and 'scholarship' as methods. For getting a better grasp gives a closer look to the literature discussing the crucial problem of the difference between reading, analysis and interpretation of literary texts, and their usefulness. The text aims to challenge the traditionally imagined diving line between hard and soft sciences by giving attention and priority to their similarities and interrelatedness for arguing that human studies have a primary and essential importance for the humankind.

Kulcsszavak: olvasás, szövegelemzés, értelmezés, hálózat, szemiotika, humán tudományok, neuroesztétika, irodalomterápia

Keywords: reading, text analysis, interpretation, networks, semiotics, humanities, neuroesthetics, book therapy 
Gyakran feltett kérdés, hogy mire ,jók” a humán vagy bölcsészeti tudományok, amelyeket szinte temetni készülnek napjainkban. A humán tudományok gyors leértékelődésének látszata részben a tudományterületek átalakulásából és egymásba fonódásából fakadhat. Egyes tudományágak besorolása a mai napig nem egyforma a világon, például a pszichológia az USA-ban természettudománynak számít, míg Európában társadalomtudománynak (Török, 2005, 596.). A bölcsészettudományok a hét nagy tudományterület egyikeként a nemzetközi ,philologia" fejléc alatt számos tudományágat fognak össze: történelem-, irodalom-, nyelv-, filozófiai, pszichológiai, nevelés- és sport-, néprajzi és kulturális antropológiai, müvészet- és müvelődéstörténeti, vallás-, média- és kommunikációs, könyvtár és színházi, valamint multidiszciplináris bölcsészettudományok. A mai magyar tudományterületi besorolás a Nemzeti Kutatási, Fejlesztési és Innovációs Hivatal pályázati honlapján tekinthető meg. Márkus György szerint a humán tudományok a müvészetek és tudományok paradox egységében e két pólus közti „senkiföldjén” helyezkednek el (Márkus, 2017, 11., 81.).

Az agykutatás újabb kísérleti eredményei kimutatták, hogy az olvasás ugyan nem túlélési szükséglete az emberiségnek, de nélküle lényegesen fejletlenebb szerkezetü aggyal éljük le az életünket. Kísérlettel is bizonyított, hogy pusztán az olvasás képessége, még ha csak felnőttként sajátítjuk el, akkor is tartós és sok területre kiterjedő agyi fejlődést eredményez már fél éven belül (Dockrill, 2017). Javítja az érzelmi intelligenciát és az empátiát, és ezzel a társas viszonyokat, szélesebb értelemben a társadalmat teszi jobbá. A társas viszonyok, akárcsak mások szándékainak jobb megértése és tetteik kikövetkeztetése az egyén boldogulását közvetlenül segíti elő (Thompson, 2017). Minél jobban edzésben tartjuk egy leírt cselekmény követésének képességét, annál könnyebben értjük a körülöttünk zajló eseményeket és a bennük megnyilvánuló, embereket mozgató szándékokat. Az olvasás még szervileg is fejleszti a kognitív képességeket, a látásért felelös és a beszédet müködtetö központokat, agyi gyógyításra is alkalmas mértékben (Miller, 2010). Mindez fokozottan érvényes az elemzésre.

A humán tudományok azzal foglalkoznak, ami nem látható és nem kézzelfogható. Mindenkire jellemzők a láthatatlan dolgok, minden embernek van lelki élete, érzelmei, szabályozatlan gondolatai. A halálról gondolkodáshoz például a tudomány nem ad individuális válaszokat, míg a művészet segíthet ezek előhívásában és a müvészet kutatása ezek tudatosításában. A láthatatlan dolgok kutatása az emberek életminőségével közvetlenül összefüggő szükséglet, amelyhez szorosan csatlakozik a materiális tudományok több ága is. Az érzelmek kutatásának óriási perspektívát adott, hogy a neurobiológiai kutatások láthatóvá tették müködésüket. A tudományok közötti vizsgálódások tágra nyitják a kapukat többek között a neuroesztétika igen fiatal területén is. Az esztétikai élmény érzelmi és fiziológiai összefüggéseinek vizsgálata pedig a megismerési, kognitív képességek és folyamatok útjait és módjait fedezi fel. 
De vajon mire jók a bölcsészeti tudományok, például az irodalomtudomány? Mi a szépirodalom olvasása és elemzése között a különbség?

Az olvasás, elemzés és irodalomkutatás általános válaszok igényét ébresztik fel, ami a fogalmi gondolkodást nem kevésbé segíti elö, mint például a matematika. Ennek nagy jelentősége van az oktatás minden fokán, hiszen ha a fejlesztendő területek valamelyike kimarad vagy háttérbe szorul, nem teljesedik ki a kreatív személyiség. (Olyat már hallottam, hogy az informatikusok kapnak némi zeneismereti képzést az egyetemen, de hogy irodalomoktatásban részesülnének, olyat nem.)

Nádas Péter írja, hogy már gyerekkorában az irodalom a „sok olvasástól az emberi viselkedésformák példatárává, a világos beszéd vagy a leleplezettség terepévé változott" (Nádas, 2017, II/175.). Közismertek az élet és irodalom szerves és gyakorlati kapcsolatára rámutató általános gondolatok, hogy az irodalom segít élni és megérteti velünk a világot (Tzvetan Todorov), hogy útmutató az élethez (Roland Barthes), hogy tudástár és tanít (Italo Calvinót idézi Antoine Compagnon) (Jeney, 2016, 152.). Az irodalom emberi érzelemre gyakorolt hatását vizsgáló tudományág, az irodalomterápia vagy biblioterápia gondolata mindössze száz éve merült fel, gyakorlata néhány évtizednyi múltra tekinthet vissza. Az érzelemkutatás az olvasó pszichikumára gyakorolt hatást helyezi középpontba, vagyis az olvasóközpontú irodalomtudomány (reader-response criticism) részeként a pszichológia, mégpedig a kognitív pszichológia irányában tájékozódik. Mint Marcel Proust írja $A z$ olvasásról címü esszéjében, a könyvek a neuraszténiás betegek számára a terapeuták szerepét játsszák. Hatásesztétikáknak is nevezhetnénk az ehhez hasonló megközelítéseket, amelyek olyan klasszikus esztétikai fogalmakra összpontosítanak, mint a katarzis és azonosulás, vagy a kánonképzés, illetve a társadalomtudományok számára is oly lényeges kultuszformálás.

Az irodalom oktatásához és tanulásához alapvető annak tudatosítása, mi a különbség az élvezeti olvasás és elemzö olvasás között. Ezt a különbségét már az iskolás gyerek is jól ismeri. A két olvasási mód, az értelmező és „érzelmező” (beleélö) olvasási fokozat között nem érdemes értékkülönbséget tenni. Különösen, mert az élvezetért olvasókból lesznek az elemző olvasók, hiszen egy idő múlva felmerül bennük a kérdés, mivel is hat rájuk a szöveg, mit csinál velük, miért jó olvasni. Van, aki a kétféle olvasási módot „írói” és „olvasói” (writerly, readerly) módnak nevezi, ami félreérthető lehet. Egy kísérletben ráadásul megkülönböztettek irodalmi, népszerü irodalmi és nem irodalmi szövegeket is: és az irodalmi szövegek olvasóinak empátiakészségét találták a legmagasabbnak (Kidd-Castano, 2013). Az élvezeti beleélő olvasás az első olvasásra jellemző - ilyenkor a hév annyira elragadhatja az embert, hogy a szokásosnál is gyorsabban falja az oldalakat, és bekezdéseket ugrik át. (Számos más olvasási mód létezik az átlapozástól az aprólékos kiadói szerkesztői olvasásig, a lektori olvasáskor pedig oly mértékben figyelhetünk a nyelvhelyességre, hogy akár a szöveg értelme is háttérbe szorulhat.) 
A kötelező olvasmányok iránti ellenérzés csupán egy lélektani beállítódás, amelyet már igen fiatalon szabályozni tud az érdeklődő elme. A kétféle olvasás közti különbség vizsgálatára elvégzett kísérletekre olyan személyeket kértek fel, akik már könnyedén tudtak váltogatni a kettő között: irodalommal foglalkozó doktoranduszokat. Itt „élvezeti” és ,alapos” (másképpen szoros vagy, mondhatnánk, lassú és figyelmes) olvasásnak nevezték (pleasure reading, illetve close reading). A „close reading” a New Criticism szakszavaként vonult be a köztudatba, a külső, vagyis életrajzi, társadalmi, ideológiai, lélektani szempontok mellőzésével, a szövegre magára, annak apró részleteire koncentráló elemzési módként. Az alapos olvasás közben, mint azt kísérlettel kimutatták, az agyi aktivitás intenzívebb, több agyterületre terjed ki, és új idegi kapcsolódásokat mutat, de az is bebizonyosodott, hogy még az olvasásélvezet mértéke is ugrásszerüen fokozódott (Jones, 2015). Egy másik újabb megközelítés a distant reading, amely mintegy felülről tekintve tárgyára, a kultúra egészére koncentrál, a könyvek szerepét vizsgálja egyes korokban. Kvantitatív adatokkal operálva hagyománytörténeti és ezért némileg pozitivista szemszögből a tudás szerkezetét topografizálja (Moretti, 2007; 2017a). De létezik materiális filológia is.

Az értelmezésbe vagy interpretációba nagy önbizalommal kezdhet bele mindenki, hiszen csak az ő személyes tudásától és világszemléletétől függ az eredmény. Mint egy nagy irodalomesztétikai alapvetés utolsó oldalán olvassuk, „annak a képessége is emberről emberre változik, hogy az »objektíve« adottat egyáltalán magunkba fogadjuk-e, mert eltérő az esetileg szükséges tárgyi tudás, a müveltség, az érzékeny, differenciált, átfogó öntudattal való ellátottság mértéke stb." (Horn, 2017, 385.). Az irodalmi élvezet létrejötte is az egyéntől függ.

Az oktatott elemzés kezdetekor nem foglalkozhatunk azzal, jó-e vagy rossz egy irodalmi mü, mert minden szöveg elemezhetö, noha nyilván olyan szövegeket boncolgatunk szívesen, amelyekben elég kihívást találunk az elemzéshez. Nem lehet eleve feltett cél az sem, hogy ideológiai vagy közvetlen morális ítéleteket hámozzunk ki a szövegekből - az irányzatos vagy rendelésre készült ideologikus írásokból (és akár kutatásokból) rendszerint kilóg a lóláb, nem szorulnak elemzésre. Az oktatásban a célkitüzés csak a módszerre vonatkozhat: a szövegek sokoldalú leírása, majd egy érveléssel alátámasztott összkép kialakítása, amely a szövegtényekből kibontja azok szerepét, összefüggéseit és müködését. Eredménye egy koherens, minden szétágazó elemében az értelmezést képviselő gondolati séma, amely nyitott további, illetve másfajta értelmezésre is.

Aki irodalmat oktat, szembesül a kérdéssel, mi tanitható az irodalmi értelmezés terén. Egzakt tudományokban szokás hangoztatni, hogy tanítani csak azt lehet, amire egy válasz van, és az tudományosan bebizonyított. Amiröl nincs tudományos megegyezés, az csak felvetésként tanítható, s mivel a jelek és a jelentés közötti többértelmüség a művészet alapja, feltételesek a kijelentések. „Az irodalomtudomány kétséges tudomány" - írja egy egykori szemiotikus (Zholkovsky, 
2015/2016, 95.). Mit nevezhetnénk „bizonyítottnak” az irodalomtudományokban, amikor még a történelmi vagy irodalomtörténeti korszakolás is csak feltételes segítség az idő tagolásához és a jelenségek összehasonlításához? A módszerek és szövegkezelési készségek viszont taníthatók (Miröl is szólnak azok a könyvek címmel készülő írásom erről szól).

„Ha mérni tudjuk, amiről beszélünk, és számokkal ki tudjuk fejezni, akkor tudunk valamit róla, de ha nem tudjuk mérni, ha nem tudjuk számokkal kifejezni, akkor tudásunk szegényes, és nem kielégítő. Lehet ez a tudás kezdete, de gondolataink ekkor még éppen csak elindultak a tudomány felé" - írta Lord Kelvin ír matematikus és fizikus 1883-ban (Kelvin, 1893, 73.). Azóta nagy fejlödésen ment és megy keresztül a tudomány egésze. Kétségtelen, hogy az esztétikai vagy poétikai alapfogalmak sohasem alkalmazhatók olyan szabályszerủen a szövegekre, mint egyes természettudományos terminusok. A strukturalizmus izgalmas statisztikai és szerkezeti képletekkel, kódokkal tudott operálni, például az időmezőket elnevezte T1-nek és T2-nek (lásd Time), vagy felmérte az ismétlődéseket, a kommunikációs elemeket, és ezekből szemléltető ábrákat készített. Háromféle, egymásra épülő interpretációt különböztet meg Petőfi S. János egzakt tudományosság igényével fellépő szemiotikai könyvében: leírót, értelmezőt és értékelőt. (Azonban nála is belopakszik a tudatos szerzői szándék megfejtési igénye és a hagyományos pszichológiai olvasat [Petőfi, 1994].) Nincs azonban kétség, hogy sem az irodalom alapanyaga, a nyelv, sem tárgya, az ember nem jellemezhető mérésekkel. Egy szöveg nem értékesebb vagy jobb attól, hogy nagyon sok mủvészi eszközt alkalmaz, nem határozza meg értékét a terjedelme, szereplöinek mennyisége vagy éppen külalakja, megjelenése sem.

A történettudomány egzaktságának tétele is megkérdőjelezendö, amint az Hayden White nagyhatású elmélete tette 1966-ban, amikor elöször mutatott rá, hogy a történész éppen olyan szépírói, fikciós módon konstruálja saját történelemképét, ahogyan a szépíró dolgozik. Nem leírja a múltat, hanem a fennmaradt szórványos tényeket világnézetének megfelelően rendezi el, hogy tudományos módszerekkel ugyan, de mégis fiktív ,igazságot” kreáljon. A nyomok és lenyomatok káoszából épített elbeszélés a felejtés ellenében ható valóságkonstrukció, egy esztétikai építmény, nem pedig az egyetlen igazság rekonstrukciója (White, 1966, 1973).

A természettudomány tárgya, a természet sem hajlandó állandó és pontos sémákba rendeződni, és kutatóit újabban éppen az foglalkoztatja, hogy sérüléseiben, szerkezeteinek váratlan alakulásában milyen fontos szerep juthat a véletlennek. A részecskefizika-kutatás egyik legújabb nagy „humán” tanulsága, hogy a szimmetriák soha nem tökéletesek, a rendszerek soha nem teljesen szabályszerüek. Ahogy a müalkotások természetéhez, úgy a fizikai és matematikai rendszerekhez is hozzátartozik a rendszerek felborítása, a pontatlanság, a belső dinamika és a feszültség, a véletlenek erővonalai (Nagy, 1982; Patkós, 2015, 39-74.). 
A matematikai kutatás aktuális fő iránya, a hálózatkutatás a valószínüség-számítási algoritmusok, gráfok, mátrixok kutatásából nőtt ki. A diszkrét matematika, amelyben a magyar kutatók és csoportjaik élen járnak, Erdős Pál kifejezésével a „sejtések müvészetének” nevezi a problémák megoldási folyamatában a helyes kérdésekre való rátalálást, hiszen a helyes kérdésfelvetés részben már magában rejtheti a választ. A 'probléma' kifejezés önmagában érzékelteti azt a metaforikusan végtelen sorozatot, amelyben egyetlen kérdés sincs lezárva, mert egy megoldás nyomban újabb problémákat vethet fel, mert vagy más összefüggésekbe kapcsolódik, vagy még kisebb részletekre irányítja a figyelmet (Lovász, 2012a, 2012b).

A diszkrét matematika meghatározása egy hasonlattal érthető meg jobban. Ha elképzeljük, hogy egy tüzetes vizsgálathoz egyre közelebb hajolunk egy tárgyhoz, képhez vagy anyaghoz, akkor a nagyításban hirtelen feltünik annak apróbb részletekből álló szerkezete, mert nem folytonosak például egy kép pixelei vagy egy textil, illetve bármely más anyag hézagai. A diszkrét, magyarul különálló részek kapcsolata is érdekes, de elszigetelve is vizsgálható egy kis részlet, mert önmagában egy újabb szerkezetet tár fel. Ez a hasonlat a szövegre is érvényes: ha csak egyetlen elemzési szempontból indulunk ki fejtegetéseinkben, például a szerkezetet vizsgáljuk, akkor az hamarosan elvezet a teljes mü más összefüggéseihez, ahogy az elméleti matematika is egy nagyobb problémahálózat számára készíti megoldásait. (A fejtegetés nagyon alkalmas szó a problémamegoldásra, mert a szöveg is szövet.)

Fentiek változatlan formában érvényesek a szövegek elemzésére is, sőt a gráfokat leíró fogalmak további tipológiai párhuzamokat ajánlanak, amelyek az elemzésekben hasznos gondolattérképek rajzolásához köthetők az általam javasolt elemzési módszerben, hiszen azok is felfoghatók hálózatoknak. A gondolattérképek használata az üzleti életben, az államigazgatásban és bármely munkafolyamat-tervezésben egyformán hatékony módszer.

Gyümölcsöző a Szemerédi-féle regularitási lemma alaptétele is a szövegekre vonatkoztatva. A nagyon nagy gráf (hálózatrendszer) fogalmát szintén alkalmazhatjuk metaforaként a szövegre - annak minden eleme közelebbi vagy szorosabb kapcsolatban áll (vagy hozható) egymással. Az alaptétel úgy hangzik, hogy minden nagy struktúra három rész együttesére bontható le, egy szigorúan strukturált váz, egy véletlenszerü raj és egy kis hiba „szuperpozíciójára”. Vagyis elég, ha a lényeges vonásait tudjuk, azzal már jellemezhetö. A szövegröl is elmondható ugyanez, nem szükséges végtelenségig feldarabolni, és minden elemét apróra értelmezni ahhoz, hogy megtaláljuk a jellemző részleteket (a dominánsokat), és megalkossuk a vázból az összképet. A hálózat legfőbb jellemzője, hogy többszörös kapcsolódásokat lehet vele átlátni és ábrázolni is.

A nagy gráfok vizsgálatakor felteendő kérdéseket is vonatkoztathatjuk a szövegekre. Elég sürü-e? Sokan telített, gazdag vagy sürü szövegnek hívjuk a sok 
elemzést, aprólékos olvasást igénylö értékes irodalmi alkotásokat, és találkozunk híg és ezért nehezen elemezhetö, sablonos szövegekkel is, amelyekről kevés a mondanivalónk. Összefüggő-e? Modellezhető-e? Hol vannak az élei (kapcsolatai)? Mik a csomópontjai? Mi a hálózat összetartó eleme, az ún. gél? - sorolta a kérdéseket Lovász László 2018. február 15-i előadásában az MTA-n. Amit az elméleti hálózattudós az internetről, a világegyetemről vagy az agyról kérdez, azt vele kérdezhetjük a szövegekröl. A metaforákként kezelt fogalmak akár le vagy meg is fordíthatók - a szövegben a gél a koherenciát adó elemek összessége, mint például a nyelvhasználat, a stílus. NB. a gél halmazállapot fogalma egy metafora, a matematikus szakszóként kölcsönözte az anyagleírásból, de metaforaként se kocsonyának, se zselének nem fogja hívni. A tudományos leírások metaforikus, azaz irodalmi nyelvet használnak, ami a nyelv alapköve (lásd Kövecses, 2008). Lényegében minden tudomány irodalmi eszközöket használó leírásoknak köszönhetően válik közérthetővé. Íme, egy matematikus metaforikus válasza a kérdésre, hogy mindegyik probléma biztosan megoldható-e. ,...ez valami olyasmi, mint egy gótikus templom: fel kell építeni az elemekböl, amelyeket először szintén meg kell alkotni, csak a végén jön a torony”. Egy kollégája kutatásáról mondja, hogy „....már egy nagyon fontos »követ« letett az asztalra” (Bán, 2008, 753.).

A hálózatok jellemzőek világunkra, akár láthatók, akár láthatatlanok. Az irodalom szavakból álló, nyelvtani elemekkel vagy jelentést hordozó szerkezetekkel összekötött hálózat. Az irodalmi művek tudományában a hálózatkutatás nemcsak a cselekményelemzésre (Moretti, 2017b), de kézenfekvő módon a szereplők közti kapcsolatok megértésére, a műfajok fejlődésére, a térszerkezetre, az intertextuális kapcsolatok összevetésére és egy sor más jellemzőre alkalmazható. A hálózatkutatás legnagyobb újdonsága, hogy olyan területek értelmezhetők hálózatként, amelyekről eddig ezt nem feltételeztük, és ez új tartalmakat tár fel. Nem kevésbé hálózatszerủ a szöveg és az irodalom, mint az emberi kapcsolatok kisebb és nagyobb közösségei, agyunk szerkezete, testünk belső információ- és anyagcseréje, a számítógépek kapcsolódása az internet világhálójával, a tápláléklánc, az árszerkezet, a világ gazdasága és kereskedelme és a térképre rajzolható utak (Barabási, 2016). A hálózatelmélet megértése és használata magas szintủ matematikai képzettséget igényel. Barabási Albert-László érdekes példát hoz a hibátlan, de haszontalan hálózatokra: például össze lehet kötni az egymással azonos keresztnevü személyeket. Erről el tudna töprengeni jó pár humán tudomány, az irodalmi névkutatás pedig azonnal tartalmas megfigyeléseket tud tenni például azoknak az irodalmi múveknek a kapcsolódásáról, ahol Ivánnak, Mátyásnak vagy Máriának hívják a hőst, hogy ez milyen másodlagos kulturális jelentéseket hordoz.

Az irodalomról írott tudománynak is vannak objektívan leírható szövegtényei, de ezekkel szubjektív igazságokra törekszik. Az alkotói szubjektum által létrehozott objektív szöveg az a tárgy, amelyet az elemző szubjektuma szubjektívan értelmez, de mégis objektívan leírhat. Az a bizonyos madárka azonban, mint Es- 
terházy Péter mondja egy interjúban az igazságról, soha nem bizonyosság, nem egyetlen és nem végleges: „Az igazság (stb.) nem olyan, mint egy tárgy, amelyet birtokolni lehet. Sőt, nemde ha valaki birtokolja, akkor a másik nem. Hanem egy folyamat (gondolkodás, munka, ima) során... nem is az, hogy jutunk el hozzá, mert akkor megint ott lennénk a birtoklásnál, hanem e folyamat során jön létre az, amit keresünk, és minden pillanatban bírjuk és nem bírjuk, amit keresünk. [...] Attól tartok, sosem lehet elégedetten hátradőlni a karosszékben, mondván, révbe értünk, megvan a madárka a kalitkában, igazság, hit, tudás. Persze valami ilyesmit szeretnénk, [...] és persze, hogy valamiféle kerek világképre vágyunk. És ezért aztán „kerekítünk”. Bizonyosságok nélkül nem is lehet élni.” (Szabó, 2009, kiemelés H. Zs.)

Esterházy Péter, aki matematika szakot végzett, úgy vélte, az egzakt matematikai tudást nem értékeli eléggé a közvélemény, mert a mủveltséget csak humán területen értelmezi, és botor módon nem tartja műveletlenségnek a matematikai járatlanságot.

Az esztétikai élményt már biológiailag is konkretizálta az idegtudomány, pontosabban annak egy fiatal ága, a neuroesztétika. A mediális orbitofrontális kéreg aktiválódása jelzi a szépségélmény átélését (és annak fokát). A szépség forrása lehet vizuális, zenei, matematikai és erkölcsi is, de az élmény a kiváltó „,inger”, alkotás vagy esemény jellegétől függően más és más agyterületek aktivizálódásával kombinálódik. Hogy valamit szépnek találunk vagy sem, az (állítja az agykutató) lehet biológiailag öröklött és kulturálisan öröklött. Utóbbin az értendő, hogy minél több jelentését ismerjük, minél jobban értjük, annál szebbnek tünik. A gyermeklélektan régen tudja, hogy a mesék és dalok ismétlése alapvető szükséglete a kisgyermeknek, mert biztonságérzetét is fokozza. Amit többször látunk, azt szebbnek is találjuk (Pak-Reichsman, 2017). Ez alátámasztja azt a két régi, ezért iskolásnak tünő tanácsot, hogy az elemzés megkezdéséhez rengeteg háttérismeret is szükséges, és hogy nem elég csak egyszer átfutni a müveket.

Az elemzés annak elhatározása, hogy időt és figyelmet szentelünk valaminek, kiigazodunk benne, és ezzel sajátunkká tesszük. Ez egy biológiai folyamat, az agytevékenység velünk született „kisajátítási” képessége nagyrészt önkéntelen. A modern agykutatás filmet is készített az agyi pontok bekapcsolódásának folyamatáról, mégpedig csecsemők agyáról, amint feldolgoznak egy információt. Az inger hatására az egyetlen pontból induló mozgás fokozatosan behálózza az egész agyat, és elérheti annak egészen távoli területeit is (ez videón megtekinthető: URL1). Már jó száz éve rámutatott a Wolfgang Köhler, Kurt Koffka és Max Wertheimer nevéhez füzödő Gestalt-elmélet, hogy az emberi agy asszociációk útján terjeszti ki müködési szféráját, és von be újabb és újabb területeket a gondolkodásba egy kérdésről, arra törekedve, hogy egyrészt, az új impulzusokat beillessze eddigi tapasztalatai közé, hasonlóságokat keressen, 
másrészt, az újak közötti eddig még nem ismert kapcsolatokat hozzon létre, és rendszert teremtsen.

A kétféle mủbefogadás közül az elemző (és nem beleélő) olvasás a másodszori és sokadszori olvasásban úgy valósul meg, hogy az írott szöveget már nem a valódi világra vonatkoztatva, puszta történetként, hanem távolságtartással, intellektuálisan vizsgálja az elme. Kihívásnak veszi, hogy kapcsolatokat keressen, ismeretei közé illessze, az ismeretlen elemeket megértse, ehhez újabb ismereteket szerezzen be. Mozgósítja elvont gondolkodását, miközben sajátjává gyúrja, még talán új fogalmakat is gyárt, rendszert próbál építeni, elméletet konstruál, és eközben saját világához méri - jelentéseket tulajdonít a szövegnek.

Umberto Eco, a szemiotika sztárja állítja, hogy ő nem elsősorban irodalomtudósokat nevelt ki szemiotikai megközelítéseivel. Hallgatói elsajátítottak egy elemzői szemléletet, amely az élet minden területén hasznosítható, az irodalmon kívül más jelenségekre is alkalmazható, hiszen minden irányzat egy módszer arra, hogyan ruházzuk fel jelentéssel a világot (Ritupsz, 2016, 11-12.). Értelmezésre vár minden életdarabka, és nincs olyan ember, aki ne asszociálna. Az emberi lényekre biológiailag jellemző asszociációk nemcsak rendszerezésre és fejlesztésre, de bátorításra és tudatosításra is várnak. Az elemzés tanulási gyakorlatának eredménye éppen olyan, mint bármiféle más készség, rutin, jártasság vagy szakismeret. Megvannak az eszközei és módszerei. Igen fontos a módszer efféle leszürése. Ennek mesterfokát mutatják az irodalomtudományi irányzatok, amelyek lecsenghetnek, de belölük a módszerek leszürendők. Egy hasonlattal élve, amikor az orvos az egyedi esetből, adott betegségből kiemeli a jellemző tüneteket, hogy megállapítsa a betegség típusát, utána ebből már általánosítva tudományos következtetést von le, majd később gyógyítási módszert formál.

A mủelemzés (interpretáció) javarészt értelemtulajdonításnak tekinthető. Bármit is fedezünk fel benne, arról nem állítható, hogy tudatos szerzői fogás, csupán annyit, hogy mi minek látjuk. A szöveg szerveződése és nyelve biztos objektív alap, és van tudományos eszköztár arra, hogy ezt megragadjuk. Az is körvonalazható, mi jellemző egy müben az írójára, más müveivel összefüggésben. Nem tudhatjuk, mi az, amit a szerző közvetíteni akart, hiszen róla és az ő gondolkodásáról aligha tudhat más ember bármit is. (Magunkat is kevéssé ismerjük, és nem látunk bele a hozzánk legközelebb álló emberek gondolkodásába sem.) Továbbmenve: nem is érdekes, hogy a szerző szándéka mi lehetett, hiszen esetleg a szövegéből egészen más derült ki, mint ami akár a kimondott szándéka volt.

Umberto Eco, aki fiatal szemiotikusként nyitott müről, a lehetséges elemzések végtelenségéről és az elemző szabadságáról beszélt, később szigorúbban kezelte az értelmezés határait, és hermetikus szemiózisnak nevezte el azt a túlértelmezö viszonyt a szöveghez, amikor a mü minden elemének jelentését keresve a makroés mikrokozmoszt, valamint metafizikai és fizikai kapcsolatait kutatta, gyakran a természettudomány, múvészetek és humán tudomány kölcsönviszonyában. 
A kultúra nem olyan adottság, mint a természet körülöttünk. Ha viszont az egzakt kutatások alaprendszereihez hasonló módszerekkel többé-kevésbé tudományosan rögzített terminusokat alkalmazunk, nemcsak egyértelmübb lesz a szakbeszéd (diszkurzus), nemcsak jobban értjük egymást, hanem hidat verünk a kétfajta terület és tudomány közé, valamint elősegítjük további gondolkodásunkat, a kategóriák segítségével hasonlóságokat és különbségeket kereshetünk korok, szerzők és müvek között. Minden münek van címe, szerkezete, hősei, időés térkeretei, képrendszere, sajátos nyelve, viszonya más irodalmi müvekhez és a szerzői életmühöz - ezek vizsgálata tanítható terminusokkal közmegegyezéses alap lehet az oktatásban. Persze, ha hiányzik a mücím, az is sokatmondó, de a „mücím” elemzése erről is szólni fog. Eközben a terminusok újraértelmezése vagy újak bevezetése akár állandóan folyhat a tudományban, a fenti vonatkoztatási lista állandó.

Minden kor olvasója mást lát meg egy-egy szövegben, ezért is derülhet ki újra más és más egy szövegből. Homérosz múveiben is új és új rétegeket lát meg a mai kutató. Minden kor újrafordíthatja Shakespeare-t vagy Platónt saját nyelvére, mert a müfordítás is értelmezés. Minden olvasói szemszög is más, és végső soron azt sem kötelező tudni, ki a szerző, a szöveg önállósodva éli életét. Mintha egy olyan könyvet olvasnánk, amelynek elveszett a címlapja. A szerzőt már jóval Roland Barthes ,a szerző halott” szlogennel fémjelzett elmélete előtt leválasztotta a müről az orosz formalizmus. Ennek ellenében született az 1920-as évek elején Mihail Bahtyin töredékben maradt, de nagy jelentőségű filozófiai műve, amely az ekkor domináns elméleti formalizmussal szállt vitába, és csak 1979-ben posztumusz jelent meg oroszul, A szerzó és a hős (Bahtyin, 2004). Ebben megkülönböztette azt a szerzőt, aki a hős és az olvasó mellett a mủalkotás ,léteseményét” belülről formáló erő is lehet, és azt a szerzőt, aki fizikai létrehozója a szövegnek, és rálát hősére, aki az ő esztétikai alkotása. (Megelőlegezve a Wayne Boothtól származó és Paul Ricoeur által továbbfejlesztett ,implied author”, implicit szerző igen hasonló fogalmát.) Egy mủ azonban kétségtelenül másképpen érthetö, ha nincs abból az időből és térből kiszakítva, amelyben az ún. empirikus (a művet létrehozó és azon kívül álló) szerző élt és alkotott, ugyanakkor tisztán esztétikai szempontból a szerző jelentősége korlátozott.

A kognitív irodalomtudomány teoretikusa, Normann N. Holland szerint a befogadó tevékenysége kizárólagos, maga a szöveg még a szintaktika elemi szintjén sem játszik szerepet az értelmezésben. Ezzel érvel Wolfgang Iser felfogásával szemben, aki szerint a jelentés a szöveg és az olvasó interakciójának eredménye (Jeney, 2016, 192.).

Egyfelől az objektív humán szaktudományok (retorika, stilisztika, lélektan, narratológia, történelem stb.) alapfogalmai, másfelöl a szubjektív olvasói és elemzői gondolatmenet kettősséget és dinamikus egyensúlyt hoznak létre. Ebben va- 
lósulhat meg az a törekvés, hogy egy szövegbe a saját kreatív gondolati építményünkön keresztül avatódjunk be. Mint látható, az irodalomelmélet újra és újra fogódzót keres, hogy tudományos kategóriákkal operálhasson. Ez a tágító folyamat egyre több tudományágat kapcsol be az irodalom tárgyalásába, amely így nyer multidiszciplináris vagy transzdiszciplináris jelleget.

\section{IRODALOM}

Bahtyin, M. (2004): A szerző és a hös. (ford. Patkós É.) Budapest: Gond-Cura Alapítvány

Bán L. (2008): A kombinatorika és a séta mestere. Beszélgetés Szemerédi Endre matematikussal. Magyar Tudomány, 169, 6, 753-761. http://www.matud.iif.hu/08jun/12.html

Barabási A. L. (2016): A hálózatok tudománya. (ford. Kirchner E.) Budapest: Libri Kiadó

Dockrill, P. (2017): Learning to Read Can Rewire Deep Parts of the Adult Brain in Just 6 Months. Science Alert. Humans, 26 May. https://www.sciencealert.com/learning-to-read-can-rewireeven-the-deep-parts-of-the-adult-brain-in-just-6-months

Horn A. (2017): Az irodalomesztétika alapjai. Budapest: Reciti Kiadó, http://reciti.hu/wp-content/ uploads/irodesztalap_vn.pdf

Jeney É. (2016): Biblioterápia, irodalomterápia. Helikon, 2, 151-155. https:/iti.btk.mta.hu/images/ kiadvanyok/helikon/Helikon 2016 2.pdf

Jones, J. (2015): This Is Your Brain on Jane Austen. The Neuroscience of Reading Great Literature. Open Culture, 14th July. http://www.openculture.com/2015/07/this-is-your-brain-on-jane-austen-the-neuroscience-of-reading-great-literature.html

Kelvin, Lord Thompson, W. (2012): Electrical Units of Measurement. May 3. 1893. Popular Lectures and Addresses. Cambridge: Cambridge University Press, I, 73-136.

Kidd, D. C. - Castano, E. (2013): Reading Literary Fiction Improves Theory of Mind. Science, 18 Oct., 377-380. https://www.researchgate.net/publication/257349728_Reading_Literary_Fiction_Improves_Theory_of_Mind

Kövecses Z. (2008): A metafora. Gyakorlati bevezetés a kognitív metaforaelméletbe. Budapest: Typotex Kiadó

Lovász L. (2012a): A Szemerédi regularitási lemma (közérthetően?). November 6. http://web.cs.elte.hu/ lovasz/PPT/szemered-abel-magy.ppt

Lovász L. (2012b): Prímek, számítógépek és Abel-díj. A természet világa, 6, 242. http://www. termeszetvilaga.hu/szamok/tv2012/tv1206/lovasz.html

Mar, R. A. (2011): The Neural Bases of Social Cognition and Story Comprehension. Annual Review of Psychology, 62, January, 103-134. http://www.annualreviews.org/doi/abs/10.1146/ annurev-psych-120709-145406

Márkus Gy. (2017): Kultúra, tudomány, társadalom. A kultúra modern eszméje. Budapest: Atlantisz Kiadó

Miller, G. (2010): How Reading Rewires the Brain. Science, 11 November. https://www.sciencemag.org/news/2010/11/how-reading-rewires-brain

Moretti, F. (2007): Graphs, Maps, Trees - Abstract Modells for a Literary History. London-New York: Verso

Moretti, F. (2017a): Gráfok, térképek fák. (ford. Vásári M.) Helikon, 2, 193-215.

Moretti, F. (2017b): Hálózatelmélet, cselekményelemzés. (ford. Kaszai M.) Helikon, 2, $216-257$. https://iti.btk.mta.hu/images/kiadvanyok/helikon/Helikon_2017_2.pdf 
Nádas P. (2017): Világló részletek I-II. Budapest: Jelenkor Kiadó

Nagy T. (1982): Szimmetriák a modern fizikában. In: Weyl, H.: Szimmetria. Budapest: Gondolat Kiadó, 187-195.

Pak, F. A. - Reichsman, E. B. (2017): Beauty and the Brain: The Emerging Field of Neuroaesthetics. The Harvard Crimson, 10 November. http://www.thecrimson.com/article/2017/11/10/ neuroaesthetics-cover/

Patkós A. (2015): Az elbüvölt fizikus. Budapest: Typotex Kiadó

Petőfi S. J. (1994): A jelentés értelmezésének vizsgálatáról. A mondatszemiotikától a szövegszemiotikáig. Tanulmányok. Párizs-Bécs-Budapest: Magyar Mủhely

Ritupsz, A. (2016): „Podozhdi, podozhdi! ne mogu! ne mogu”. Interviu s Umberto Eko. Rigas Laiks, leto, 10-14.

Szabó B. (2009): Interjú Esterházy Péterrel. Hajónapló, XIV, 7, 14-15.

Thompson, B. N. (2017): Theory of Mind: Understanding Others in a Social World. Psychology Today, 3 July. https://www.psychologytoday.com/blog/socioemotional-success/201707/theory-mind-understanding-others-in-social-world

Török Á. (2005): A társadalomtudományok fejlődése és az akadémiai osztályszerkezet. Magyar Tudomány, 166, 5, 596-605. http://www.matud.iif.hu/05maj/14.html

Vekerdy T. (1995): „Hányszor sír Nemecsek?” Kerekasztal-beszélgetés a gimnáziumi irodalomoktatásról. Kritika, 4, 15.

White, H. (1966): The Burden of History. History and Theory, Vol. 5, No. 2, 111-134. DOI: $10.2307 / 2504510$

White, H. (1973): Metahistory. The Historical Imagination in Nineteenth-Century Europe. Baltimore: Johns Hopkins University Press, https:/quod.lib.umich.edu/cgi/t/text/text-idx?c=acl$\mathrm{s} ; \mathrm{cc}=$ acls; view $=$ toc;idno $=$ heb04928.0001.001

Zholkovsky, A. (2015/2016): Bolshie slova i malenkiie veshchi. Interviu, Los Angeles, 2013. Rigas Laiks, zima.

URL1: https://www.youtube.com/watch?v=wBciB2eW6_8

\section{FÜGGELÉK}

Az érzékelt és látott dolgok feldolgozási különbsége alkalmas arra, hogy az írott szöveg befogadásának néhány sajátosságát felismerjük. Egy kép láttán a szem akaratunktól függetlenül pásztázza a látottakat. Ezt a szemmozgást rá is lehet rajzolni aztán a látott képre. Ezen jól látható, hogy mely területek maradtak ki, és melyekre koncentrálódott nagyobb figyelem (egy egyszerủ ablakra nem fókuszált a szem, elég volt a térlátással befogni, míg a kisebb tárgyakra és föleg az emberi arcokra vissza is tért a tekintet). A szövegolvasás közbeni szemmozgást még nem figyelték, de egy könyv lapjain elörefelé szokás haladni, hiszen a nyelv lineáris sor, a szavak egymás után következnek. Viszont éppen az elemzéshez, akár már az első olvasáskor is jó módszer a visszalapozgatás, a távolabb eső részekhez való visszatérés, összefüggéseik keresése.

Az egyéni olvasási szokásokba beletartozhat az is, hogy előre megnézi valaki a könyv végét, illetve lapozgatva pásztázza a könyvesbolti vagy könyvtári döntés elött, érdekli-e az adott könyv. Létezik ún. gyorsolvasás is, amely a szem térlátását fejlesztve nem szavakat, hanem szókapcsolatokat, majd sorokat, később több sort, sőt egész oldalakat ragad meg egy-két pontra fókuszálva. Ez a fajta olvasás szépirodalmi elmélyüléshez nem alkalmas, megkönnyíti viszont az újságolvasást és a tájékozódást olyan szövegekben, amelyekkel csak globálisan ismerkedünk, vagy amelyekben újraolvasáskor keresünk. 
A kétféle befogadás vizuális analógiája lehet a színes és a fekete-fehér fotók agyi feldolgozásának különbsége. A színes képek láttán az agy a szemböl érkező információkat „,csak” lebontja, míg a fekete-fehér képeket saját belső látását és emlékeit mozgósítva kiszínezi, hozzáadja a színeket a szürke árnyalataihoz, például egy fa képéhez a levelek megjelenítéséhez a zöld árnyalatait. Elöször a gyermekpszichológia figyelt fel arra, hogy az olvasás közben történő belső képalkotás elengedhetetlen a kisgyermek fejlődéséhez. (Ennek különösen nagy irodalma született a televízió elterjedésekor, az olvasást kiszorító tévézés veszélyeiről. Lásd Vekerdy Tamás „Hányszor sír Nemecsek?" [1995]. Az internet elterjedése nyilván újabb helyzetet teremtett.)

Alighanem a szöveg „kiszínezése” (megértése, elemzése) is ehhez hasonló folyamat. Sokszor tapasztalt csalódás, ha egy-egy kedvenc könyvünk új kiadása más illusztrációkkal, elképzelt hősünk új arccal jelenik meg, vagy ha egy filmváltozat megtestesíti ugyanezt a hőst, és az nem olyan, mint a belső képünk volt. (A filmadaptációk óhatatlanul átírják a regényeket, hiszen mások a müfaji követelmények, arról nem is beszélve, hogy az irodalom legfontosabb jellemzöje, a megformált szöveg nyelve és stílusa, a szóban előadott kiegészítendő, nyitott értelmezést váró képek „elvesznek”.)

Mit jelent az, hogy egy mủvészeti alkotás elemzése elhatározás kérdése? Egy múzeumban eldönthetjük, hogy csak néhány pillanatig állunk egy kép elött, amíg kiderül, tetszik-e, vagy akár pár percet is gyönyörködünk benne. Egészen más viszonyunk lesz a képhez, ha tüzetesen megvizsgáljuk, milyen apró elemeit tudjuk felfedezni, illetve ha még a múzeumon kívül is ismereteket gyüjtünk a képről, az alkotóról, más műveiről, kortársairól és korszakáról és így tovább. Irodalmi mű esetén a „gyönyörködés” megfelelője a részleteknél elidőzés, illetve a nem is egyszeri újraolvasás. A müélvezeti és tudományos elemzés között az érzelmi agyterületek bevonódása jelenti a különbséget. Az egyedi ismeretek hálója és a személyes érzelmek asszociatív, nem általános érvényü, szövevényes és egyedi rendszerré formálják az irodalmi elemzést.

Iskolai környezetben hangzott el a szülöi kérdés, hogy miért kell magyar nyelvtant tanulni annak, akinek az anyanyelve magyar. És ha mindenki tud beszélni, írni és olvasni, akkor miért kell az irodalomról tanulni? Éppen a természettudományos kontextus segíthet a válaszadásban. Mindenki ösztönösen megtanul enni, amit megeszik, megemészti, de ha nem érti, hogyan zajlik az anyagcsere, könnyebben lesz beteg, egészségtelenül élhet, és orvoshoz fordul az első kisebb jelre, amit még nem tapasztalt a testében. Mit és hogyan együnk? Hogyan gondolkozik az agy? A válaszok, a megértés tudatos életet tesz lehetővé, ami érinti saját egyéniségünket, sőt gyerekeink nevelésében is érvényesül. Vagyis hozzájárul ahhoz, hogy önmagunk és környezetünk is egy koncepciónak megfelelően alakuljon, egészséges önképünk alakuljon ki, része legyen identitásunknak. Hasonló a mechanizmusa az irodalomról való elemző gondolkodásnak is, ezért alakult ki az a hagyomány, hogy a művelt embert többre tartja a környezete. Aki elemez, nem tárgyi tudását, hanem a világról és önmagáról alkotott tudását gazdagítja, önmagát fejleszti. 